\title{
Revisiting the Debate of Grammar Teaching: A Young Scholar's Perspective
}

\author{
Mohammed Sadat \\ Department of Public Relations Management, University of Professional Studies, Accra
}

\begin{abstract}
The debate of grammar teaching has taken center stage in the Second Language Acquisition (SLA) literature over a long period of time. Most of these debates emanate from distinguished scholars like DeKeyser, Long and Ellis. This paper seeks to add to the debate the views of an emerging scholar in the field of SLA. The paper addresses the key questions related to grammar pedagogy in SLA. It discusses whether grammar should be taught and if so, when and how. More importantly, the paper points to alternative solutions to each problem related to grammar teaching. The paper explores the most current debate in the grammar teaching by evaluating the validity of the arguments advanced in the debate. The evaluation is based on the key issues going on in the debate. The paper considered the debate as a healthy one that will give a positive and appropriate way towards teaching useful grammar. The paper suggests that language instructors should take into consideration different aspects regarding; what, how, when, and why should grammar be taught. Also, the paper recommends that teaching grammar should depend on the level of the learners, therefore a good teacher should always teach based on the levels of the learners.
\end{abstract}

Keywords: grammar teaching, second language acquisition, emerging scholar

\section{Introduction}

Grammar teaching is one of the controversial areas in language teaching. However, some language instructors consider grammar teaching very important because it helps learners discover the nature of language. Learning the rules of a language explains the structure and the form of the language into details and this helps the learner to understand the very nature of language. Ellis (2005) outlines 10 principles of instructed learning. The principles are guidelines that provide suitable conditions for adult second language learners and offer teachers direction for teaching grammar to adult learners. Also, Ellis (2006a) identifies and discusses the current issues related to teaching of grammar in SLA. According, to Ellis (2006a), there are eight key questions related to grammar pedagogy in SLA and these questions need to be considered with all the attention they deserved in relation to grammar teaching. The questions are:

(1) Should we teach grammar?

(2) What grammar should we teach?

(3) When should we teach grammar?

(4) Should grammar instruction be massed or distributed?

(5) Should grammar instruction be intensive or extensive?

(6) Is there any value in teaching explicit grammatical knowledge?

Mohammed Sadat, Department of Public Relations Management, University of Professional Studies, Accra. 
(7) Is there any best way to teach grammar for implicit knowledge?

(8) Should grammar be taught in separate lesson or integrated into communicative activities?

Basically, these questions address whether grammar should be taught and if so, when and how.

There has been a war among scholars on grammar teaching in language acquisition. However, it seems there is some kind of agreement among the language practitioners that grammar teaching works for language learners. The practitioners in the field of teaching have argued on whether learners should be taught the language rules or a condition should be created for them to learn the language in a natural way. Either way leads to language acquisition but one may lead to more and faster acquisition than the other depending to where one belongs to. There is also an issue of the timing of grammar teaching in SLA. While some see early grammar teaching is best way to go others want grammar teaching to be taught in later years until the learners have already acquired some linguistic competence. They think that this will lead to easier acquisition of grammatical features when learners start learning the grammar. There is also a divided opinion on whether the grammar teaching should be allocated to a very short period or it should be spread over long period of time. I believe that grammar teaching should be spread to a long period of time because this will give the learner an ample time to acquire the necessary features of the language.

An opinion is also divided on whether grammar teaching should be taught intensively to cover a single grammatical structure in a single lesson or many grammatical structures should be taught extensively in a single lesson. I believe the former should be the way to go because it will provide the learner the time to take the topics one after the other. If learners are taught extensively in a single lesson, it will be difficult for them to understand because a situation of "information overload" may occur.

This paper seeks to discuss the views of a young language practitioner on the most current debate in the teaching of grammar and evaluates the validity of the arguments advanced in the debate of teaching grammar. The evaluation is based on the key issues going on in the debate of teaching grammar.

\section{Grammar Teaching}

Grammar teaching is one of the aspects of teaching that aids in the teaching and learning of a language. Grammar teaching can be considered as a description of the grammar of a language that is designed for teaching and learning purposes. Ellis (2006a) identifies two types of definitions of grammar teaching: narrow definition and broad definition (p. 84). With the narrow definition, Ellis (2006a) describes grammar teaching as the traditional grammar teaching (TGT) that involves "presentation and practice of discrete grammatical structures" (p. 84). The presentation has to do with the explanation of the rules of the language whereas the practice captures the various activities a learner will take in the process of teaching and learning.

Most grammar book writers support this kind of grammar teaching description. Ur (1996) and Hedge (2000) also considered grammar teaching based on the "presentation and practice". This definition has reduced the grammar teaching to only the "presentation and practice"; however, grammar teaching does not always consist of "presentation and practice" because we have forms of grammar teaching that this definition does not captured. We may have instances where grammar teaching may consist one of the following:

(1) Presentation and practice;

(2) Presentation without practice;

(3) Practice without presentation;

(4) None of the above. 
Ellis (2006a) defines the broad definition of grammar teaching as the one that: “...involves any instructional technique that draws learners' attention to some specific grammatical form in such a way that it helps them either to understand it metalinguistically and/or process it in comprehension and/or production so that they can internalize it" (p. 84). This definition is broad because it covers all the aspects a learner needs to have to become competent. In as much as I agree that grammar teaching involves "practice and practice", I also agree that there is more to that. For instance, in a communicative context corrective feedback can be used as a strategy to teach grammar by correcting the error in a learner's speech.

\section{Appropriate Time to Teach Grammar}

The time to introduce a topic in teaching is very crucial to the success of the teaching and learning process and grammar teaching is not an exception. There are two opposing views regarding the best time to teach grammar in language acquisition. There are those who hold the view that grammar teaching should be introduced in the early stages of L2 acquisition. This view sees this as a foundation for other aspect of language acquisition. N. Ellis (2005) says teaching grammar early is valuable because it provides a basis for the real learning that follows. According to N. Ellis (2005), learning begins with an explicit representation of linguistic forms, which are then developed through implicit learning.

On the other hand, there are also those who are of the opinion that grammar teaching should be delayed for the later years. This view wants the language instructors to concentrate on meaning. They think that if learners aware of the meanings in their interlanguage, grammar can then be introduced gradually. On this issue, I strongly believe that the later view has the prospects of facilitating language acquisition.

Ellis (2006b) says grammar teaching should be later when learners have acquired some abilities to use the language. They can learn grammar naturally and without being taught through corrective feedback. Ellis (2006a) opines "grammar is best taught to learners who have already acquired some ability to use the language (i.e., intermediate level) rather than to complete beginners" (p. 102). He claims that learners need no grammar instruction during their first years of learning. Ellis is of the view that learners can acquire a substantial amount of grammar incidentally without instruction. He added that though what is acquired is agrammatical. This is in tune with Ellis (2005) principled 5: Instruction needs to take account of the learner's built-in syllabusing (p. 216).

In response to this issues, Sheen (2006) argues that we should not compare immersion programmes which entails "students" total school time exposure to the second language (L2) with the ordinary classrooms with "2 or 3 hours of exposure a week" (p. 828). I am of the view that Ellis (2006a) points is stronger in that learners at first year will not grasp the concept of grammar but they will do so at later year if they understand a bit of the target language. Secondly, this point supports the "Natural Order Hypothesis" by Krashen (1981) which argues that grammar instruction plays no role in the development of implicit knowledge.

Ellis (2006a) claims that learners need no grammar instruction during their first years of learning. Ellis is of the view that learners can acquire a substantial amount of grammar incidentally without instruction. He added that though what is acquired is agrammatical. It means the learners are not aware of the rules being correct or incorrect. In a rebuttal on the issue of agrammaticality, Sheen (2006) describes Ellis argument as "circular" "because it is based only on research on incidental learning" (p. 829). 


\section{Approaches to Teaching Grammar}

There are divergent opinions on approach to teaching grammar. There is considerable argument as to whether grammar teaching should be based on the traditional grammar teaching (TGT) approach or on a focus on form approach. Traditional grammar teaching dominated the language teaching for so many years. Traditional grammar teaching is the type that put much emphasis on accuracy and it does not compromise on learners' errors. Ellis (2006a) describes the traditional grammar teaching approach as teaching grammar based on explicit explanations and drill-like practice. He added that it involves "presentation" and "practice" therefore too narrow for learning.

Sheen (2006) debunks this assertion by saying that Ellis has "no empirical evidence to support this claim" (p. 831). Sheen (2006) adds that "though presentation and practice are essential components, it also embraces any teaching and learning techniques which the cumulative experience of thousands of teachers using TGT have contributed to its repertoire" (p. 830). TGT has helped thousands of EFL teachers to become fluent and accurate in speaking English.

On the other hand, focus on form is the approach that lays emphasis on communicative use of language. Huang (2010) describes focus on form as the approach "where linguistic forms are addressed in a communicative language teaching context" (p. 29). Focus on form implies no separate lessons but rather teaching grammar integrated in different communicative tasks.

Task-based language teaching is also another approach of teaching grammar that has been considered as a very effective in language teaching practice. Skehan (1998) defines a task as "an activity in which meaning is primary, there is a problem to solve, there is a relationship to the real world, and where there is an objective that can be assessed in terms of an outcome" (p. 95). It means that any language teaching task given to learners should be meaningful to them and it should relate to happenings in the real world. More importantly, Huang (2010, p. 32) is of the view that a well-designed task should fulfill many of the instructed learning principles outlined by Ellis (2005).

In particular, tasks are usually performed in pairs or small groups so they provide opportunities for interaction (Principle 8) and for the learners' active use of the language (Principle 7). To complete the task successfully, the focus is on understanding and communicating meanings (Principle 2). All tasks must have a measurable outcome. An outcome that is intrinsically engaging is more likely to develop and maintain learners' intrinsic motivation (Principle 9). An important feature of a task also ensures that. Learners focus on form through a closer study of some of the specific language features at the end of the task (Principle 3).

\section{The Type of Grammar We Must Teach}

After battling with the actual time learners need grammar instruction, the next discussions is the type of grammar that needs to be taught. Here I look at the kind of grammar and the grammatical feature. According to Ellis (2006a), there is no controversy in the kind of grammar. Ellis (2006a) confirmed that syllabus designers and teachers rely on descriptive grammars that detail the form-meaning relationships of the language (p. 86). Therefore, any reference grammar that fails to describe the form-meaning connection must be inadequate. I also believe that form-meaning connection is very necessary because it provides pedagogical description of grammar and identifies the kinds of errors the L2 learners make. With this, the instructors can tell which structures need special attention. The connection between the form-meaning should be given the attention because it is the combination of linguistics forms, semantics, and the discoursal meaning. 
According to Ellis (2006a), the controversy is with the structure of the grammar. He identifies two popular positions: The first position is the minimalist position by Krashen (1982) who argues that grammar teaching should be limited to the simple and portable rules that can be used to monitor the output. Examples of the simple structures are 3rd person $-s$ and past tense -ed. They are simple so learners can learn them easily. The complex structures are difficult to learn and uneasy to monitor. Ellis (2006a) however said there is evidence that show that Krashen's argument is "unwarranted" (p. 87).

The other position is the comprehensive position which says "teach the whole grammar of the target language". Ellis (2006a) again describes the positions as "unwarranted" (p. 88). Ellis proposes two approaches that in his view can delineate the cognitive difficulty. These are:

(1) Teach those forms that differ from the learners' first language, and seem to be problematic to learners rather than teaching the whole grammar;

(2) Teach marked rather than unmarked forms.

\section{Explicit and Implicit Grammar Teaching}

There are opinions whether grammar should be explicitly or implicitly. Explicit knowledge consists of the features of language that are learnable. In other words, there are facts about language that speakers have made conscious efforts to learn. On the other hand, Ellis (2006a) describes implicit knowledge as "procedural, held unconsciously, and can only be verbalized if it is made explicit" (p. 102). It is accessed rapidly and easily and thus available for use in rapid, fluent communication. In looking at the efficacy of explicit knowledge in teaching grammar, Ellis (2006a) considered three separate questions (p. 96):

(1) Is explicit knowledge of any value in and of itself?

Ellis supports the view that learning explicit knowledge is not effective if there is absence of opportunities for practicing the target feature.

(2) Can explicit knowledge transfer into implicit knowledge?

To answer this question, Ellis provides three positions:

(a) Non-interface position:

It means there is no way that explicit knowledge development can facilitate the development of implicit knowledge.

(b) Interface position:

This is the situation where there is correlation between the explicit knowledge and implicit knowledge. Explicit knowledge may assist language development by facilitating the development of implicit knowledge. This can only occur if the learners have ample opportunity for communicative practice.

(c) Weak-interface position:

Ellis (2006a) claims that explicit knowledge can convert into implicit knowledge if the leaner is ready to acquire the target feature and that this conversation can occur priming a number of key acquisitional processes in particular noticing and noticing gap.

According to Ellis, teaching explicit grammatical knowledge can be done in any of the following ways:

(1) Focus-on-forms approach;

(2) Focus-on-form approach;

(3) Deductive;

(4) Inductive. 
In addition, Ellis (2006a) mentions the difference between input-based and production-based instructions, and different types of correcting feedback under the implicit knowledge (p. 98). The input based takes place when the learners comprehend and process the input. The production based occurs when learning occurs out of social interaction. This approach aids learners to produce new grammatical structures. Ellis added that corrective feedback is important for learning grammar. It is best conducted using a mixture of implicit and explicit feedback types that are both input based and output based. Long (1988) also mentions that teaching grammar is beneficial but that to be effective grammar had to be taught in a way that was compatible with the natural processes of acquisition.

\section{Conclusion}

The controversy of teaching grammar remains unsolved. Ellis (2005) acknowledges the fact many of that statement made about teaching grammar remain controversial. As a language teacher, this discussion helps language teachers to decide positive and appropriate ways towards teaching useful grammar. Any language instructor should take into consideration different aspects regarding, what, how, when, and why should we teach grammar? Also, teaching grammar will largely depend on the level of the learners, therefore a good teacher always teaches based on the levels of the learners. More importantly, the paper suggests that language instructors should blend grammar teaching with Communicative Language Teaching in order to achieve both linguistics and communicative competence in the classroom.

I consider the type of grammar that needs to be taught as the most heated argument in grammar teaching and it will remain unsolved for some time to come. Who decides the difficult part of grammar or the less difficult part? However, this debate should not stop us from teaching grammar, but should rather encourage us to undertake research in order to come out with best or the less controversial method of grammar teaching. It seems most language teacher believe that grammar teaching really works for learners but we should bear in mind that explicit teaching is unlikely to result in the acquisition of the implicit knowledge which is very crucial for fluent and accurate communication.

\section{References}

DeKeyser, R. (1998). Beyond focus on form: Cognitive perspectives on learning and practicing second language grammar. In C. Doughty and J. Williams (Eds.), Focus on form in classroom second language acquisition (pp. 42-63). Cambridge: Cambridge University Press.

Ellis, N. (2005). At the interface: Dynamic interactions of explicit and implicit language knowledge. Studies in Second Language Acquisition, 27(2), 305-352.

Ellis, R. (2005). Principles of instructed language learning. In P. Robertson, P. Dash, and J. Jung (Eds.), English language learning in the Asian context (pp. 12-26). Pusan: The Asian EFL Journal Press.

Ellis, R. (2006a). Current issues in the teaching of grammar: An SLA perspective. TESOL Quarterly, 40(1), 83-107.

Ellis, R. (2006b). The author replies. A balanced perspective. Replying to Sheen. TESOL Quarterly, 40(4), 833-837.

Hedge, T. (2000). Teaching and learning in the language classroom. Oxford, England: Oxford University Press.

Huang, H. (2010). Grammar instruction for adult English language learners: A task-based learning framework. Journal of Adult Education (Information Series), 39(1), 29-37.

Krashen, S. (1981). Second language acquisition and second language acquisition. New York: Pergamon.

Krashen, S. (1982). Principles and practice in second language acquisition. London: Pergamon Press Inc..

Long, M. H. (1988). Instructed interlanguage development. In L. Beebe (Ed.), Issues in second language acquisition: Multiple perspectives (pp. 115-141). Rowley, MA: Newbury House.

Sheen, R. (2006). Comments on R. Ellis's “Current Issues in the Teaching of Grammar: An SLA Perspective”. A reader responds. An SLA perspective. TESOL Quarterly, 40(4), 828-832. 
Skehan, P. (1998). A cognitive approach to language learning. Oxford: Oxford University Press.

Swan, M., \& Walter, C. (2006). Readers respond: "Teach the whole of the grammar". TESOL Quarterly, 40(4), 837-839.

Ur, P. (1996). A course in language teaching. Cambridge, England: Cambridge University Press. 